\begin{tabular}{|c|c|c|}
\hline$\exists$ & $\begin{array}{c}\text { International Journal of Current Research } \\
\text { and Academic Review }\end{array}$ & \\
\hline $\begin{array}{l}\text { EXCELLENT } \\
\text { PUBLISHERS } \\
\end{array}$ & $\begin{array}{c}\text { ISSN: 2347-3215 (Online) } \\
\text { Journal hompage: } \text { http:///www.ijcrar.com } 3 \text { (March-2017) }\end{array}$ & \\
\hline
\end{tabular}

doi: $\underline{\text { https://doi.org/10.20546/ijcrar.2017.503.011 }}$

\title{
Microbial Air Quality in Medical Laboratory Rooms at Benghazi Center of Infectious Diseases and Immunity
}

\author{
Muna M. Buzayan ${ }^{1}$ and Fauzia R. El-Garbulli ${ }^{2}$ \\ ${ }^{1}$ Kaser Ahmed Hospital, Misurata, Libya \\ ${ }^{2}$ Department of Botany, Faculty of Science, Benghazi University, Benghazi, Libya
}

*Corresponding author: buzayanone@yahoo.com

\section{Abstract}

The control of indoor air quality plays an important role in the prevention of cross infection in hospitals to protect both hospital staff and patients. This study was carried out to determine the variation in microbiota of medical laboratory at Benghazi center infectious diseases and immunity. Samples were collected by using the settled plate techniques for the enumeration of bacterial and fungal isolates. The air specimens were collected through four seasons in the morning between the hours of 9 am and 11 am from air indoor medical lab and swab samples collected from the filters of the air conditioning units in autumn, spring and summer seasons. Indoor air gram positive bacteria, accounting (99.72\%) was significantly higher than that of gram negative bacteria $(0.28 \%)$. The most common bacteria genus found in all seasons were Staphylococcus (46.62\%) Micrococcus $(27.31 \%)$, followed by Kocuria $(13.42 \%)$. Micrococcus luteus and Kocuria rosea were found frequently occurring airborne bacterial isolates in the four seasons. Gram negative bacteria were only found in autumn and summer seasons only. Rest room had the highest bacterial count (43.47 $\left.\mathrm{CFU} / \mathrm{m}^{3}\right)$ while the microbiology room had the lowest $\left(3.66 \mathrm{CFU} / \mathrm{m}^{3}\right)$. The susceptibility pattern of all isolates revealed sensitivity to all tested antibiotics. Aspergillus spp., Penicillium spp. and Alternaria spp. were frequently dominant air borne fungal isolates. Bacterial concentration $\left(0.26 \mathrm{CFU} / \mathrm{m}^{3}\right.$ air $-38.49 \mathrm{CFU} / \mathrm{m}^{3}$ air $)$ in investigated filters of air conditioning unites while fungal concentration was $(0.26$ $\mathrm{CFU} / \mathrm{m}^{3}-51.59 \mathrm{CFU} / \mathrm{m}^{3}$ ). The most abundant isolated bacteria in the three seasons was Bacillus circulans while Penicillium sp. was the most abundant fungi in air conditioning isolates. In indoor air samples of medical laboratory rooms showed contamination with bacteria and fungi under the acceptable levels, when compared with cited in this study. Indoor airborne bacteria and fungi concentration were depended on place of isolation and seasons.
\end{abstract}

\section{Article Info}

Accepted: 28 February 2017

Available Online: 20 March 2017

\section{Keywords}

Bacteria, Fungi, indoor air rooms, medical laboratory, microbial air quality.

\section{Introduction}

Most biological contamination of indoor air is caused by bacteria, moulds and yeast (Aboul-Nasr et al., 2011).
Indoor air problems have been associated with a decrease in employees' comfort, work efficiency and may also be the cause of some work-related symptoms and diseases (Reijula and Sundman-Digert, 2004; Mahbob, 2011). 
In indoor environments, the main source for microbes is mainly originated from outdoor sources (Shelton et al., 2002; WCB Publication, 2005). In addition to outdoor sources, indoors microbes can originate from indoor sources. These can be the occupants themselves and their activities (Ferro et al., 2004; Kopperud et al., 2004). Other factors influencing the microbial population include building maintenance, cleanliness, indoor temperature and relative humidity, type of furniture, and carpeting (Ross et al., 2004; Mandal and Brandl, 2011; Park et al., 2013).

The control of indoor air quality (IAQ) plays an important role in the prevention of cross infection in hospitals to protect both hospital staff and patients. Poor hospital IAQ may cause outbreaks of sick hospital syndrome (SHS), causing headaches, fatigue,Sneezing, eye and skin irritations, and other symptoms (Leung and Chan, 2006; WCB Publication, 2005).

Previous studies showed that the microbial flora of the indoor air depends on several factors including the number and hygiene of people who occupy the building (Ekhaise et al., 2008; WCB Publication, 2005), The physical layout of the building, the quality of the hospital system and mechanical movement within the enclosed space (Ekhaise et al., 2010, WCB Publication, 2005).

The counting of microbes in air is not an easy. There are different methods of choice for sampling airborne microbial loads (Pasquarella et al., 2000; Jaffal et al., 1997). Each method has strong and weak points, and in general more than one is necessary to accurately assess most situations (Jaffal et al., 1997). However, Culturing is the conventional method for microbial characterization, although it underestimates total microbial concentrations (Amann et al., 1995).

The present study was aimed togain knowledge regarding the air quality of medical laboratory indoor air and, to determine the types of airborne micro-flora in the medical laboratory at Benghazi center infectious diseases and immunity (BCIDI). The data can be used to set standards for levels of acceptable microbial population.

\section{Materials and Methods}

Cross sectional study conduct to measure indoor air microbial quality of medical laboratory rooms of BCID from October to July 2013-2014. The Samples were collected in four seasons of the year. About 38 samples each season from indoor air and 11 samples from air conditioners collected by using Settle Plate Method (Passive Air Sampling) on blood agar for bacteria culture (Genet et al., 2011; Kelkar and Kulkarni, 2011) and Sabouraud's Dextrose Agar (SDA) plate plus $50 \mu \mathrm{g} / \mathrm{ml}$ of gentamicin for fungi culture (Kelkar and Kulkarni, 2011).

Each plate was leaving open to the air for a 30 minutes (Kelkar and Kulkarni, 2011), a meter to $1.5 \mathrm{~m}$ above the floor and a meter from the wall (Ekhaise and Ogboghodo, 2011). The air samples collected (at 9-11 AM) within a given day. The blood agars settle plate then incubate at $35-37^{\circ} \mathrm{C}$ for $24-48$ hours (Ekhaise and Ogboghodo, 2011) while the fungal culture plates are incubate at room temperature $\left(22^{\circ} \mathrm{C}-26 \mathrm{C}\right)$ for $3-7$ days (Ekhaise et al., 2010; Garcia-Cruz et al., 2012; Kelkar and Kulkarni, 2011; Bhaita and Viskwakarma, 2010).

The number of microorganisms expressed as colony forming unit $\left(\mathrm{CFU} / \mathrm{m}^{3}\right)$ was estimated according to the equation (Stryjakowska-Sekulska et al., 2007; Bhaita and Viskwakarma, 2010):

$\mathrm{CFU} / \mathrm{m}^{3}=\mathrm{a} \cdot 10000 / \mathrm{p} \cdot \mathrm{t} \cdot 0.2$

Where:

a - the number of colonies on the Petri plate

$\mathrm{p}$ - The surface of the Petri plate

$\mathrm{t}$ - The time of Petri plate exposure

Isolation of Bacteria and fungi was performed by sub streaked on the same medium to obtain pure colonies. Bacterial colonies were identified by using gram stain, API 20E (bioMerieux, France) and/or Phoenix ${ }^{\mathrm{TM}}$ Automated Microbiology System (Becton Dickinson, USA) (BD) of the isolates. The fungal colonies were identified based on colony appearance and microscopic examination of the spore and hyphae (Barnett and Hunter, 1998; Koneman and Roberts, 1992; Chaturvedi and Ren, 2007; Ellis et al., 2007).

The Antibiotic susceptibility test was done on MuellerHinton agar (MHA) (BD) by using Kirby-Bauer disk diffusion method according to the British society for antimicrobial chemotherapy (BSAC) guidelines (BSAC, 2011). Staphylococcus aureus ATCC25923 and Escherichia coli ATCC 25922 strains were used as control organisms. The antibiotics were: Ampicillin 
$(10 \mu \mathrm{g})$, Amikacin $(30 \mu \mathrm{g})$, amoxycillin-clavulanic acid $(30 \mu \mathrm{g})$, ceftriaxone $(30 \mu \mathrm{g})$, ceftazidime $(30 \mu \mathrm{g})$, cefotaxime $(30 \mu \mathrm{g})$, Clindamycin $(2 \mu \mathrm{g})$, Erythromycin $(15 \mu \mathrm{g})$, Gentamicin $(10 \mu \mathrm{g})$, imipenem $(10 \mu \mathrm{g})$, aztreonam $(30 \mu \mathrm{g})$, cefoxitin $(30 \mu \mathrm{g})$, trimethoprimsulfamethoxazole $(25 \mu \mathrm{g})$, ciprofloxacin $(5 \mu \mathrm{g})$, Tetracycline $(30 \mu \mathrm{g})$, Vancomycin $(5 \mu \mathrm{g})$ (Oxoid Ltd., Cambridge, UK). The results were recorded as susceptible, intermediate and resistant according to the British society for antimicrobial chemotherapy (BSAC, 2011) recommendations.

\section{Results and Discussion}

Air samples from each the sampled medical lab rooms studied were taken and used for enumeration and isolation of airborne bacteria on BA plates, and for the enumeration and isolation of airborne fungi on SDA plates. Table 1 shows microorganisms isolated from the medical lab rooms studied in four seasons.

The percentage of gram positive bacteria $(99.72 \%)$, were significantly higher than that of gram negative bacteria $(0.28 \%)$ in the air in medical lab of BCID. With regard to the bacterial groups, a total of 1054 bacterial isolates distributed across 17 genera and 33species of culture able airborne bacteria were identified from different sites (Table 1). As a whole, the most common bacteria genus found in all seasons were Staphylococcus (46.62\%) Micrococcus (27.31\%), followed by Kocuria (13.42\%), and they totally accounting for about $87.35 \%$ of culturable airborne bacteria in medical lab. The most common bacterial species identified in the air was Staphylococcus capitis sub capitis, Micrococcus luteus, followed by Kocuria rosea, contributing to $31.50 \%$, $26.94 \%$, and $11.39 \%$ of the total airborne bacteria, respectively. Micrococcus luteus and Kocuria rosea were found frequently occurring airborne bacterial isolates in the four seasons. All other bacteria were detected in small numbers or not detected in all seasons. Namely; Aerococcus, Bacillus, Dermacoccus, Globicatella, Leifsonia, Macrococcus, Kytococcus, Paenibacillus, Pantoea and Pediococcus (Table 1).

The total airborne bacterial load of the different sites studied in the medical lab during the four seasons is presented in figure 1, which showed that the rest room had the highest bacterial count $\left(43.47 \mathrm{CFU} / \mathrm{m}^{3}\right)$ then storage $\left(24.35 \mathrm{CFU} / \mathrm{m}^{3}\right)$ and coffee $\left(24.09 \mathrm{CFU} / \mathrm{m}^{3}\right)$ rooms while the microbiology room had the lowest (3.66
$\mathrm{CFU} / \mathrm{m}^{3}$ ). The bacterial concentration $\mathrm{CFU} / \mathrm{m}^{3}$ air in this medical lab was highest in autumn $\left(105.27 \mathrm{CFU} / \mathrm{m}^{3}\right)$, followed by spring $\left(62.33 \mathrm{CFU} / \mathrm{m}^{3}\right)$, and, winter $(58.93$ $\mathrm{CFU} / \mathrm{m}^{3}$ ) and lowest bacterial concentration was observed in summer $\left(49.49 \mathrm{CFU} / \mathrm{m}^{3}\right.$ ) (Figure 2). The susceptibility patterns of all isolates revealed sensitivity to all the antibiotics tested.

Gram positive bacteria appeared higher percent in autumn (38.15\%) and spring $(22.64 \%)$ than winter $(21.41 \%)$ and summer $(17.79 \%)$. Gram negative bacteria were isolated only in autumn and summer seasons $(0.28 \%)$ included Moraxella species and Acinetobacter lwoffiil haemolyticus respectively, Table 1.

149fungal isolated demonstrate to 10 genus were isolated and characterised from the different studied rooms. Aspergillus spp., Penicillium sp., Alternaria spp. were the dominant and the frequently in the four investigated seasons while Cladosporium, Candida spp., Fusarium; Gliocladium, Rhizopus, Epicoccum and Diplodia were the least frequent fungi (table 1). The highest fungal load was recorded in coffee room and storage room (5.76 $\mathrm{CFU} / \mathrm{m}^{3}, 6.02 \mathrm{CFU} / \mathrm{m}^{3}$ ), respectively while the lowest fungal load was recorded in the microbiology room $\left(0.26 \mathrm{CFU} / \mathrm{m}^{3}\right)$ (Figure 1$)$.

The degree of contamination by was calculated in percentage terms and $\mathrm{CFU} / \mathrm{m}^{3}$ (Table 1). Overall, the least frequently genus encountered was Rhizopus and Diplodia $(0.67 \%)$. The fungal counts ranged from 0.26 $\mathrm{CFU} / \mathrm{m}^{3}$ in microbiology room to $6.02 \mathrm{CFU} / \mathrm{m}^{3}$ from coffee room. The result showed the fungal $\mathrm{CFU} / \mathrm{m}^{3}$ of the autumn was higher than that of the spring and other seasons (Table 1).

33 swab Samples were collected in three seasons (autumn, spring and summer) of year from the filters of the air conditioning units (ACU). Their culturing yielded 10 genera of bacteria and 8 genera of fungi, table 2.Bacterial isolation rate was higher in reception ACU (19.37\%) than other air conditioning units (Figure 3). Fungal isolation rate was higher in biochemistry $1 \mathrm{ACU}$ (26.18\%) and microbiology $(18.33 \mathrm{CFU} / \mathrm{m} 3)$ than the other air conditioning units, figure 3 . Average number of bacteria and fungi present in ACU of different rooms in three seasons were compared in figure 3. 
Table.1 Concentration levels of the airborne bacteria and fungi isolated during four seasons

\begin{tabular}{|c|c|c|c|c|c|c|c|c|c|c|}
\hline \multirow{3}{*}{ Type and $\begin{array}{c}\text { No. of bacteria and fungi } \\
\text { isolated }\end{array}$} & \multicolumn{10}{|c|}{ Seasons } \\
\hline & \multicolumn{2}{|c|}{ Autumn } & \multicolumn{2}{|c|}{ winter } & \multicolumn{2}{|c|}{ spring } & \multicolumn{2}{|c|}{ Summer } & \multirow[b]{2}{*}{ 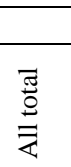 } & \multirow[b]{2}{*}{$\delta^{\circ}$} \\
\hline & $\stackrel{\Xi ّ}{0}$ & 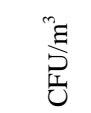 & స్ّే & $\sum_{\substack{g \\
U}}^{\xi}$ & $\stackrel{\pi}{0}$ & $\stackrel{\underbrace{}}{己}^{E} m$ & $\stackrel{\widetilde{\pi}}{0}$ & 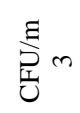 & & \\
\hline \multicolumn{11}{|l|}{ Gram Positive Bacteria } \\
\hline \multicolumn{9}{|l|}{ Micrococcus } & 287 & 27.31 \\
\hline Micrococcus luteus & 104 & 27.24 & 86 & 22.52 & 45 & 11.79 & 49 & 12.83 & 284 & 26.94 \\
\hline Micrococcus lylae & 1 & 0.26 & & & & & 2 & 0.52 & 3 & 0.28 \\
\hline \multicolumn{9}{|l|}{ Kocuria } & 141 & 13.42 \\
\hline Kocuria rosea & 9 & 1.83 & 89 & 23.31 & 2 & 0.52 & 20 & 5.24 & 120 & 11.39 \\
\hline Kocuria varians & 21 & 5.49 & & & & & & & 21 & 1.99 \\
\hline \multicolumn{9}{|l|}{ Staphylococcus } & 490 & 46.62 \\
\hline Staphylococcus capitis sub capitis & 223 & 58.40 & & & 89 & 23.31 & 20 & 5.24 & 332 & 31.50 \\
\hline Staphylococcus kloosii & 14 & 3.67 & & & 4 & 1.05 & 2 & 0.52 & 20 & 1.89 \\
\hline Staphylococcus hominis & 22 & 5.76 & & & 43 & 11.26 & & & 65 & 6.17 \\
\hline Staphylococcus haemolyticus & & & 25 & 6.55 & & & 4 & 1.05 & 29 & 2.75 \\
\hline Staphylococcus lentus & & & & & 1 & 0.26 & 2 & 0.52 & 3 & 0.28 \\
\hline Staphylococcus epidermidis & & & & & & & 22 & 5.76 & 22 & 2.09 \\
\hline Staphylococcus capitis sub urolyticus & & & & & & & 10 & 2.62 & 10 & 0.95 \\
\hline Staphylococcus saprophyticus & & & & & & & 4 & 1.05 & 4 & 0.38 \\
\hline Staphylococcus lugdunensis & & & & & & & 4 & 1.05 & 4 & 0.38 \\
\hline Staphylococcus aureus & & & & & & & 1 & 0.26 & 1 & 0.09 \\
\hline \multicolumn{9}{|l|}{ Bacillus } & 22 & 2.09 \\
\hline Bacillus cereus & & & 4 & 1.05 & & & & & 4 & 0.38 \\
\hline Bacillus thuringiensis & & & 9 & 2.36 & & & & & 9 & 0.85 \\
\hline Bacillus circulans & & & & & & & 2 & 0.52 & 2 & 0.19 \\
\hline Bacillus megaterium & & & & & & & 3 & 0.79 & 3 & 0.28 \\
\hline Bacillus coagulans & & & & & & & 4 & 1.05 & 4 & 0.38 \\
\hline \multicolumn{9}{|l|}{ Corynebacterium } & 6 & 0.57 \\
\hline Corynebacterium amycolatum/ minutissimum & & & & & & & 4 & 1.05 & 4 & 0.38 \\
\hline Corynebacterium matruchotii & & & & & & & 2 & 0.52 & 2 & 0.19 \\
\hline \multicolumn{11}{|l|}{ Others } \\
\hline Aerococcus viridans & 7 & 1.83 & & & 23 & 6.02 & 1 & 0.26 & 31 & 2.94 \\
\hline Macrococcus caseolyticus & & & 1 & 0.26 & 2 & 0.52 & 6 & 1.57 & 9 & 0.85 \\
\hline Pediococcus pentosaceus & & & 6 & 1.57 & 8 & 2.09 & 1 & 0.26 & 15 & 1.42 \\
\hline Leifsonia aquatica & & & 1 & 0.26 & & & 7 & 1.83 & 8 & 0.76 \\
\hline Pantoea agglomerans & & & 1 & 0.26 & & & 3 & 0.79 & 4 & 0.38 \\
\hline Paenibacillus alvei & & & 3 & 0.79 & & & & & 3 & 0.28 \\
\hline Dermacoccus nishinomiyaensis & & & & & 4 & 1.05 & 12 & 3.14 & 16 & 1.52 \\
\hline Globicatella sanguinis & & & & & 11 & 2.88 & & & 11 & 1.04 \\
\hline Kytococcus sedentarius & & & & & 6 & 1.57 & & & 6 & 0.57 \\
\hline Arcanobacterium pyogenes & & & & & & & 2 & 0.52 & 2 & 0.19 \\
\hline Total & 401 & & 225 & & 238 & & 187 & & 1051 & 99.72 \\
\hline Gram Negative Bacteria & & & & & & & & & & \\
\hline Acinetobacter lwoffii/ haemolyticus & & & & & & & 2 & 0.52 & 2 & 0.09 \\
\hline Moraxella species & 1 & 0.26 & & & & & & & 1 & 0.19 \\
\hline Total & 1 & & 0 & & 0 & & 2 & & 3 & 0.28 \\
\hline Fungi & & & & & & & & & & \\
\hline Aspergillus spp. & 45 & 11.79 & 9 & 2.36 & 3 & 0.79 & 9 & 2.36 & 66 & 44.30 \\
\hline Penicillium sp. & 9 & 2.36 & 13 & 3.40 & 4 & 1.05 & 6 & 1.57 & 32 & 21.48 \\
\hline Alternaria spp. & 1 & 0.26 & 5 & 1.30 & 8 & 2.09 & 3 & 0.79 & 17 & 11.41 \\
\hline Candida spp. & & & 1 & 0.26 & 5 & 1.30 & 10 & 2.62 & 16 & 10.74 \\
\hline Cladosporium sp. & 1 & 0.26 & & & 3 & 0.79 & & & 4 & 2.68 \\
\hline Gliocladium sp. & 3 & 0.79 & & & 1 & 0.26 & & & 4 & 2.68 \\
\hline Fusarium sp. & 1 & 0.26 & 4 & 1.05 & & & & & 5 & 3.36 \\
\hline Epicoccum sp. & & & & & 2 & 0.52 & 1 & 0.26 & 3 & 2.01 \\
\hline Diplodia sp. & 1 & 0.26 & & & & & & & 1 & 0.67 \\
\hline Rhizopus sp. & & & 1 & 0.26 & & & & & 1 & 0.67 \\
\hline
\end{tabular}


Table.2 Airborne microorganisms isolated from the filters of the air conditioning units

\begin{tabular}{|c|c|c|c|c|c|c|c|c|c|c|c|c|}
\hline \multirow[b]{3}{*}{$\begin{array}{c}\text { Type and No. of bacteria } \\
\text { and fungi isolated }\end{array}$} & \multicolumn{9}{|c|}{ seasons } & \multirow{2}{*}{\multicolumn{3}{|c|}{ For three seasons }} \\
\hline & \multicolumn{3}{|c|}{ Autumn } & \multicolumn{3}{|c|}{ spring } & \multicolumn{3}{|c|}{ summer } & & & \\
\hline & 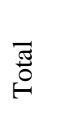 & $8^{\circ}$ & 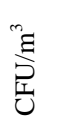 & స్ّ & 8 & 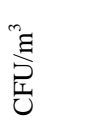 & 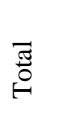 & 8 & 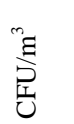 & 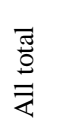 & $0^{\circ}$ & 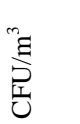 \\
\hline \multicolumn{13}{|l|}{ Bacteria } \\
\hline S. capitis sub capitis & 18 & 15.79 & 4.71 & 5 & 4.54 & 1.30 & 11 & 5.53 & 2.88 & 34 & 8.04 & 8.90 \\
\hline Staphylococcus klossii & 30 & 26.32 & 7.86 & & & & 4 & 2.01 & 1.05 & 34 & 8.04 & 8.90 \\
\hline Staphylococcus homonis & & & & & & & 23 & 11.56 & 6.02 & 23 & 5.44 & 6.02 \\
\hline Staphylococcus warneri & & & & & & & 8 & 4.02 & 2.09 & 8 & 1.83 & 2.09 \\
\hline Kocuria rosea & & & & & & & 6 & 3.02 & 1.57 & 6 & 1.42 & 1.57 \\
\hline Kocuria varians & 12 & 10.53 & 3.14 & & & & & & & 12 & 2.84 & 3.14 \\
\hline M. luteus & 36 & 31.58 & 9.43 & & & & & & & 36 & 8.51 & 9.43 \\
\hline Rhizodium radiobacter & 9 & 7.89 & 2.36 & & & & & & & 9 & 2.13 & 2.36 \\
\hline Bacillus circulans & 9 & 7.89 & 2.36 & 46 & 41.81 & 12.05 & 92 & 46.23 & 24.09 & 147 & 34.75 & 38.49 \\
\hline Bacillus cereus & & & & 34 & 30.90 & 8.90 & & & & 34 & 8.04 & 8.90 \\
\hline Bacillus coagulans & & & & 7 & 6.36 & 1.83 & & & & 7 & 1.65 & 1.83 \\
\hline Bacillus megaterium & & & & 3 & 2.72 & 0.79 & & & & 3 & 0.71 & 0.79 \\
\hline Aerococcus viridans & & & & 15 & 13.63 & 3.93 & & & & 15 & 3.55 & 3.93 \\
\hline Arcanobacterium pyogenes & & & & & & & 1 & 0.50 & 0.26 & 1 & 0.24 & 0.26 \\
\hline Corynebacterium urealyticum & & & & & & & 2 & 1.01 & 0.52 & 2 & 0.47 & 0.52 \\
\hline $\begin{array}{l}\text { Dermacoccus } \\
\text { nishinomiyaensis }\end{array}$ & & & & & & & 51 & 25.63 & 13.36 & 51 & 12.06 & 13.36 \\
\hline Enterococcus faecium & & & & & & & 1 & 0.50 & 0.26 & 1 & 0.24 & 0.26 \\
\hline Total & 114 & & & 110 & & & 199 & & & 423 & & 110.77 \\
\hline \multicolumn{13}{|l|}{ Fungi } \\
\hline Penicillium sp. & 9 & 30 & 2.36 & 92 & 53.17 & 24.09 & 96 & 63.16 & 25.14 & 197 & 55.49 & 51.59 \\
\hline Aspergillus spp. & 19 & 63.33 & & 75 & 43.35 & 19.64 & 45 & 29.61 & 11.78 & 139 & 39.15 & 36.40 \\
\hline Alternaria spp. & & & & & & & 2 & 1.32 & 0.52 & 2 & 0.56 & 0.52 \\
\hline Cladosporium sp. & 1 & 3.33 & 0.26 & & & & 3 & 1.97 & 0.79 & 4 & 1.13 & 1.05 \\
\hline Gliocladium & & & & & & & 2 & 1.32 & 0.52 & 2 & 0.56 & 0.52 \\
\hline Fusarium sp. & & & & & & & 1 & 0.66 & 0.26 & 1 & 0.28 & 0.26 \\
\hline Candida spp. & & & & & & & 3 & 1.97 & 0.79 & 3 & 0.85 & 0.79 \\
\hline Rhizopus sp. & 1 & 3.33 & 0.26 & 6 & 3.46 & 1.57 & & & & 7 & 1.97 & 1.83 \\
\hline Total & 30 & & & 173 & & & 152 & & & 355 & & 92.97 \\
\hline
\end{tabular}

Fig.1 Concentration airborne microorganisms isolated from indoor air during different sites of medical room lab

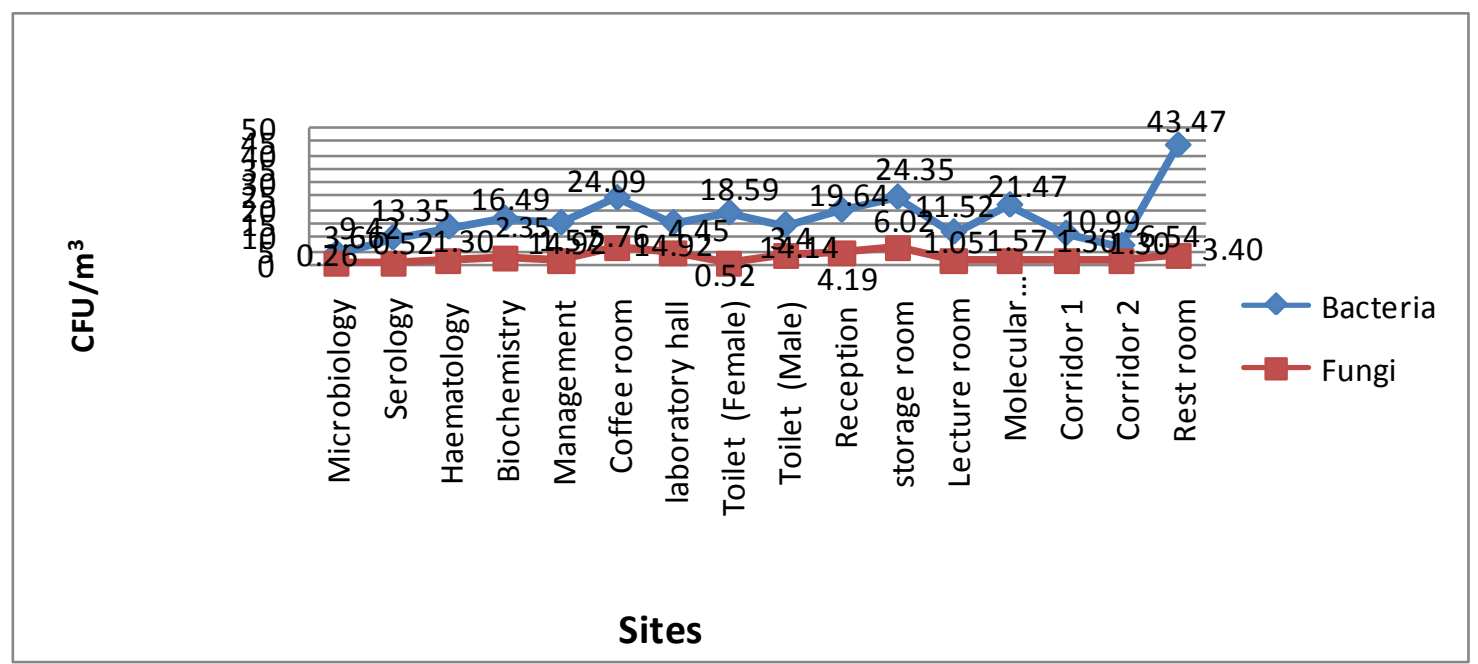


Fig.2 Concentration airborne microorganisms (CFU/m3) isolated from indoor air during four seasons

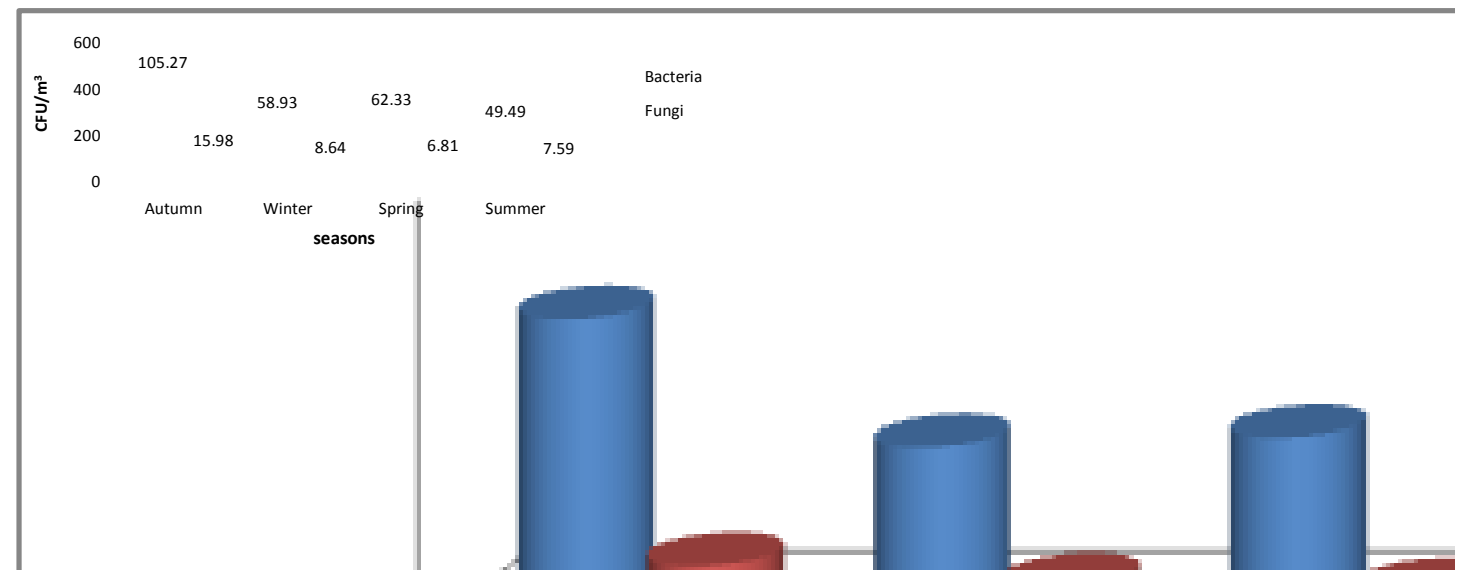

Fig.3 Concentration airborne microorganisms isolated from ACU during different sites of medical lab

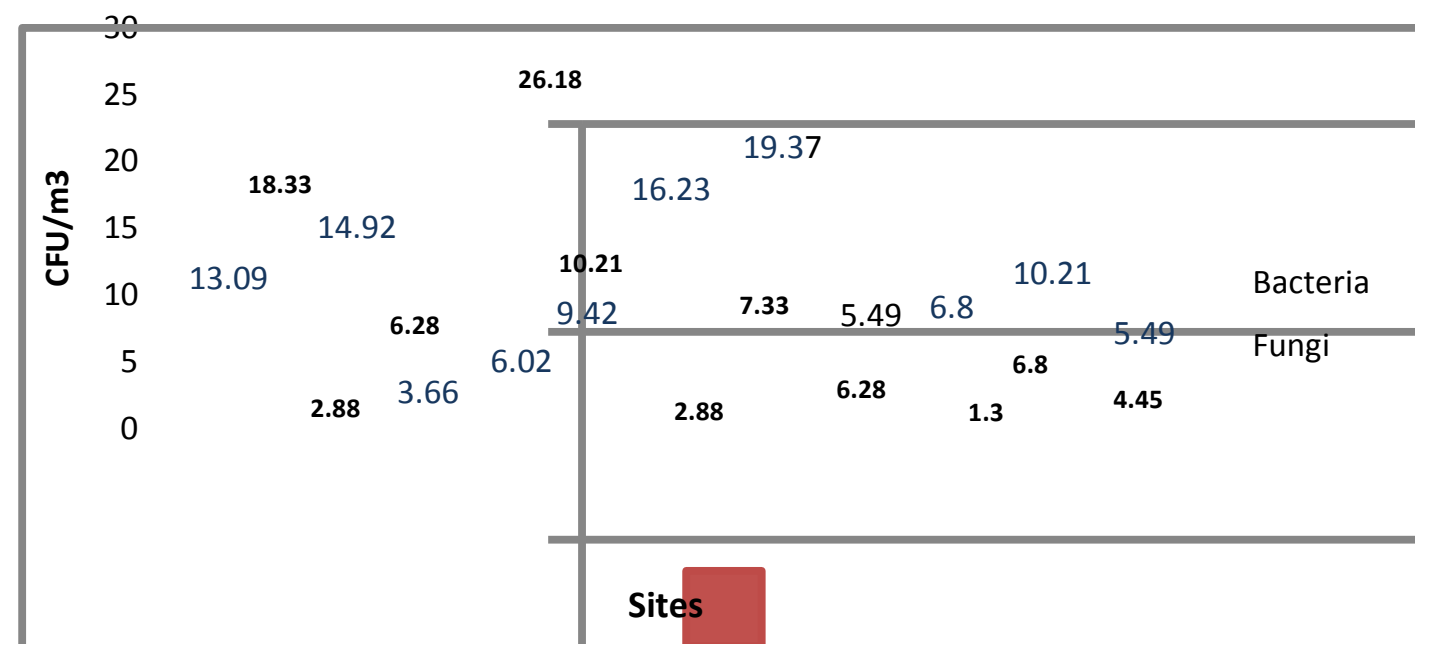

Fig.4 Concentration airborne microorganisms isolated from ACU during three seasons

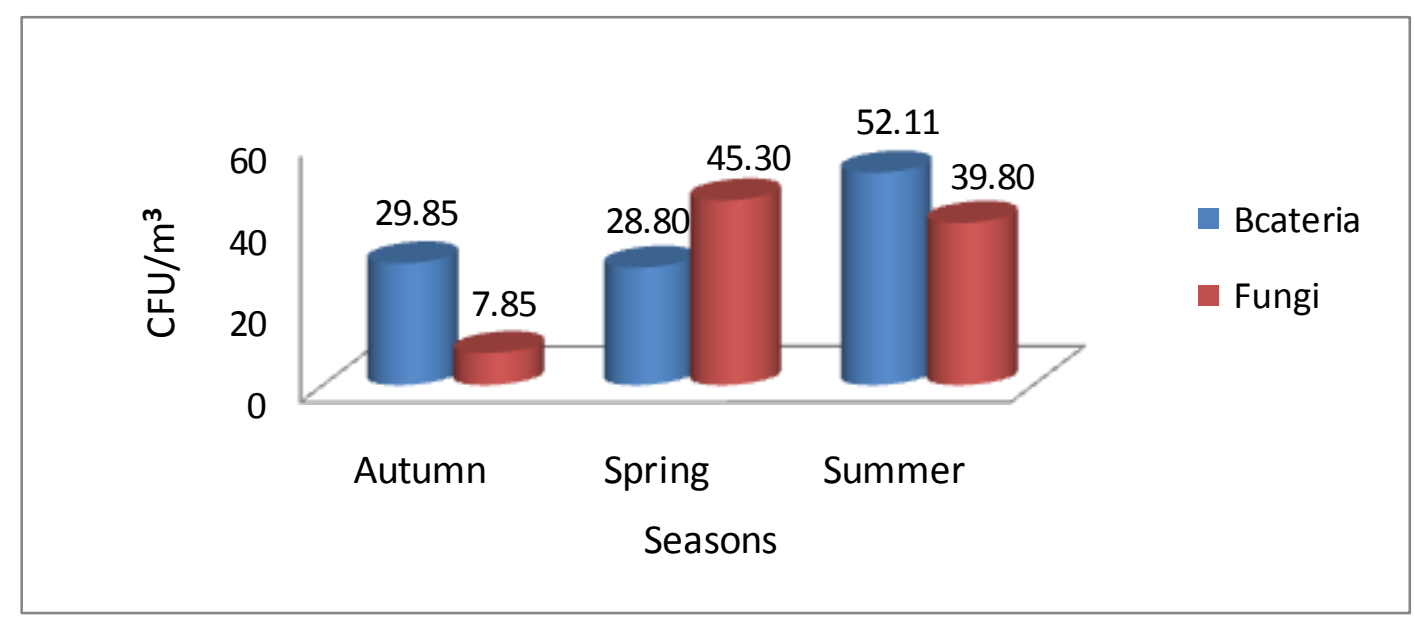


Concentrations of isolates vary depend on season and the day time. In summer season a concentration of bacteria $\left(52.11 \mathrm{CFU} / \mathrm{m}^{3}\right)$ was higher than autumn and spring respectively (29.85 $\mathrm{CFU} / \mathrm{m}^{3}$ and $28.80 \mathrm{CFU} / \mathrm{m}^{3}$ ), while the concentration of fungi was in spring higher (45.30 $\mathrm{CFU} / \mathrm{m}^{3}$ ) than autumn and summer respectively $(7.85$ $\mathrm{CFU} / \mathrm{m}^{3}$ and $39.80 \mathrm{CFU} / \mathrm{m}^{3}$ ). Variations in concentration of bacteria and fungi in ACU filters were observed in figure 4. The bacterial counts $\left(\mathrm{CFU} / \mathrm{m}^{3}\right)$ ranged from 0.26 $\mathrm{CFU} / \mathrm{m}^{3}$ to $38.49 \mathrm{CFU} / \mathrm{m}^{3}$. The fungal counts $\left(\mathrm{CFU} / \mathrm{m}^{3}\right)$ ranged from $0.26 \mathrm{CFU} / \mathrm{m}^{3}$ to $51.59 \mathrm{CFU} / \mathrm{m}^{3}$ (Table 2).

The types of microorganisms isolated from the air of the different times are shown in table 2. The most abundant of isolated bacteria in the three seasons was Bacillus circulans $\left(38.49 \mathrm{CFU} / \mathrm{m}^{3}\right)$ followed by Dermacoccus nishinomiyaensis $\left(13.36 \mathrm{CFU} / \mathrm{m}^{3}\right)$, and $M$. luteus $\left(9.43 \mathrm{CFU} / \mathrm{m}^{3}\right)$ and for fungi Penicillium $\left(51.59 \mathrm{CFU} / \mathrm{m}^{3}\right)$ then Aspergillus spp. $\left(36.40 \mathrm{CFU} / \mathrm{m}^{3}\right)$ were the most abundant in ACU. While other genes from bacteria and fungi were last frequently encountered table 2.

Air quality in medical lab is important for staff, worker health and environment. The main factor affecting the indoor bacterial concentration is the density and activities of occupants (Fox et al., 2005). The concentration of airborne microflora in air medical lab environment of BCID, showed that, rest, storage and coffee rooms (Figure 1) recorded the highest airborne bacterial and fungal population, while the least airborne bacterial and fungal population was recorded in the microbiology and serology rooms (Figure 1).

The degree of bacterial contamination in a tested area of current study was in permitted levels, according to Toth (1992) who suggested that the counting of human normal flora bacteria above $200 \mathrm{CFU} / \mathrm{m}^{3}$ air be considered high. Bacterial concentrations in homes and hospitals have varied between $10 \mathrm{CFU} / \mathrm{m}^{3}$ to $104 \mathrm{CFU} / \mathrm{m}^{3}$ in different studies (Awad and Farag, 1999; Lee and Jo, 2006; Obbard and Fang, 2003). For hospital environments, the maximum number of bacteria $\mathrm{CFU}$ allowed by the WHO (1988) is $100 \mathrm{CFU} / \mathrm{m}^{3}$.

The concentrations of gram-positive bacteria are generally higher than those of gram-negative bacteria in the indoor air (Fox and Rosario, 1994) this was in agreement with current study. Among the microbial isolate, Staphylococcus spp, was reported to be the most prevalent bacterial isolate followed by Micrococcus and Kocuria, also they were found in four seasons, while gram negative bacteria found in some of them. These airborne micro-flora obtained were similar to that obtained by Ekhaise et al., (2010).

The diversity of bacterial species present is wide and in agreement with that found by (Jaffal et al., 1997; Kim and Kim, 2007; Naddafi et al., 2011).

Indoor air samples in this study showed contamination with fungi under the acceptable levels. For the hospital environments, WHO, 1988 recommends shouldn't exceed $50 \mathrm{CFU} / \mathrm{m}^{3}$ of fungi, the National Institute of Occupational Safety and Healthy (NIOSHI-USA) (Jensen and Schafer, 1998) up to $1000 \mathrm{CFU} / \mathrm{m}^{3}$, and the Brazilian Health Ministry (ANVISA, 2000) $750 \mathrm{CFU} / \mathrm{m}^{3}$. However, Jensen Yand Schafer (1998), reinforces the fact that a low concentration of microorganisms in indoor air environments does not mean they are healthy, but needs to identify the microorganisms to evaluate the conditions of the air-conditioning systems. In this study, nevertheless, the fungal contamination levels were from 1 to $66 \mathrm{CFU} / \mathrm{m}^{3}$ for indoor samples.

Dominant indoor air fungi in this study were Aspergillus sp. $(44.30 \%)$ and Penicillium sp. (21.48\%) then Alternaria sp. (11.41\%) and Candida sp. (10.74\%). Other fungal isolates include Fusarium (3.36\%), Cladosporium (2.68\%), Gliocladium (2. 68\%), Epicoccum (2.01\%), Rhizopus and Diplodia (0.67\%). These results are comparable to those from previous study (Omolgberale et al., 2014; Qudiesat et al., 2009; Herbarth et al., 2003 and Jaffa, 1997) who also isolated similar fungi in indoor environments. Ekhaise et al., (2010) also isolated Aspergillus sp., Penicillium sp., Mucor sp., and Candida sp., Verticillium sp. from the study areas. Higher isolation rates were made at storage room and the coffee room probably due to poor ventilation, poor cleaner, and overcrowding in this study area.

\section{References}

Aboul-Nasr, M.B., El-Zoohri, A.A., and Amer, E.M. 2011. Indoor airborne mycobiota of intensive care units in Assiut University Hospitals. JES, 7: 61-66.

Amann, R.I., Ludwig, W. and Schleifer, K.H. 1995. Phylogenetic identification and in situ detection of individual microbial cells without cultivation. Microb. Rev., Vol. 59(1); 143-169.

ANVISA. 2000. Resolução n. 176 de 24 outubro de 2000, Brasília, Brasil. http://www.anvisa.gov.br. Acess 26 jan. 2001. 
Awad, A.H.A., Farag, S.A. 1999. An indoor biocontaminants air quality. Int. J. Environ. Health Res., 9(4): 313-319.

Barnett, H.L. and Hunter, B.B. 1998. Illustrated genera of imperfect fungi. Fourth edition. Minnesota, USA. $218 \mathrm{p}$.

Bhatia, L. and Vishwakarma, R. 2010. Hospital indoor airborne microflora in private and government Owned hospitals in Sagar city, India. World J. Med. Sci., 5(3): 65-70.

Britishsociety for antimicrobial chemotherapy (BSAC). 2011. BSAC Methods for Antimicrobial Susceptibility Testing. Version 10.2.

Chaturvedi, V., Ren, P. 2007. Mycology Proficiency Testing Program.Wadsworth Center, New York State Department of Health.

Ellis, D., Davis, S., Alexiou, H., Handke, R. and Bartley, $\mathrm{R}$ 2007.Descriptions of medical fungi. Second edition. Australia.

Ekhaise, F.E., Ogboghodo, B.I. 2011. Microbiological Indoor and Outdoor Air Quality of Two Major Hospitals in Benin City, Nigeria. Sierra Leone J. Biomed. Res., 3(3): 169-174.

Ekhaise, F.O., Ighosewe, O.U., and Ajakpovi, O.D. 2008. Hospital Indoor Airborne Microflora in Private and Government Owned Hospitals in Benin City, Nigeria. World J. Med. Sci., 3(1): 19-23.

Ekhaise, F.O., Isitor, E.E., Idehen, O., and Emoghene, A.O. 2010. Airborne Microflora in the Atmosphere of an Hospital Environment of University of Benin Teaching Hospital (UBTH), Benin City, Nigeria. World J. Agricult. Sci., 6(2): 166-170.

Ferro, A.R., Kopperud, R.J., Hildemann, L.M. 2004. Source strengths for indoor human activities that resuspend particulate matter. Environ Sci Technol., 38(6): 1759-64.

Fox, A., Harley, W., Feigley, C., Salzberg, D., Toole, C., Sebastian, A. and Larsson, L. 2005. Large particles are responsible for elevated bacterial marker levels in school air upon occupation. J. Environ. Monitoring, 7(5): 450-456.

Fox, A. and Rosario, R.M.T. 1994. Quantification of muramic acid, a marker for bacterial peptidoglycan, in dust collected from hospital and home airconditioning filters using gaschromatography massspectrometry. Indoor Air, 4(4): 239-247.

Herbarth, O., Schlink, U., Muller, A. and Richter, M. 2003. Sptiotemporal distribution of airborne mould spores in apartments. Mycol. Res., 107(11): 13611371.

Garcia-Cruz, C.P., Aguilar, M.J.N., Arroyo-Helguera, O.E. 2012. Fungal and Bacterial Contamination on
Indoor Surfaces of a Hospital in Mexico. Jundishapur J. Microbiol., 5(issue 3): 460-464.

Genet, C., Kibru, G., Tsegaye, W. 2011. Indoor air bacterial load and antibiotic susceptibility pattern of isolates in operating rooms and surgical wards at Jimma University specialized hospital, southwest Ethiopia. Ethiop. J. Health Sci., 21(1): 9-17.

Jaffal, A.A., Nsanze, H., Bener, A., Ameen, A.S., Banat, I.M., El Mogheth, A.A. 1997. Hospital airborne microbial pollution in a desert country. Environ. Internat., 23(2): 167-172.

Jensen, P.A. and Schafer, M.P. 1998, Sampling and characterization of bioaerosols. Manual of Analytical Methods.USA : National Institute for Occupational Safety Healthy. pp. 82-112.

Lee, J.H. and Jo, W.K. 2006. Characteristics of indoor and outdoor bioaerosols at Korean highrise apartment buildings. Environ. Res., 101(1): 11-17.

Leung, M., Chan, A.H.S. 2006. Control and management of hospital indoor air quality. Med. Sci. Monit., 12(3): 17-23.

Kelkar, U., Kulkarni, S. 2011. Contaminated air conditioners as potential source for contaminating operation theatre environment. Int. J. Infection Control, 8(issue 1): 45-48.

Kim, K.Y. and Kim, C.N. 2007. Airborne microbiological characteristics in public buildings of Korea. Building and Environ., 42(5): 2188-2196.

Koneman, E.W., Allen, S.D., Janda, W.M., Schreckenberger, P. C. and Winn, W. C. 1992. Color Atlas and Textbook of Diagnostic Microbiology. $4^{\text {th }}$ ed. J. B. Lippincott Company. Philadelphia.

Kopperud, R.J, Ferro, A.R, Hildemann, L.M.2004.Outdoor versus indoor contributions to indoor particulate matter (PM) determined by mass balance methods. J. Air Waste Manag. Assoc., 54(9): 1188-96.

Mahbob, N.S., Kamaruzzaman, S.N., Salleh, N., Sulaiman, R. 2011. A Correlation Studies of Indoor Environmental Quality (IEQ) Towards Productive Workplace. 2011. 2nd International Conference on Environmental Science and Technology. IPCBEE. 6 IACSIT Press, Singapore.

Mandal, J., Brandl, H. 2011. Bioaerosols in indoor environment - a review with special reference to residential and occupational locations. The Open Environ. Biol. Monitoring J., 4: 83-96.

Naddafi, K., Jabbari, H., Hoseini, M., Nabizadeh, R., Rahbar, M., Yunesian, M. 2011.Investigation of indoor and outdoor air bacterial density in Tehran 
subway system. Iran. J. Environ. Health. Sci. Eng., 8(4): 381-386.

National Library of Canada Cataloguing in Publication Data. 2005. Indoor air quality: a guide for building owners, managers and occupants. Workers compensation board of British Columbia (WCB Publications).

Obbard, J.P. and Fang, L.S. 2003.Airborne concentrations of bacteria in a hospital environment in Singapore. Water, Air, and Soil Pollu., 144(1): 333-341.

Omoigberale, M.N.O., Amengialue, O.O. and Iyamu, M.I. 2014. Microbiological assessment of Hospital Indoor Air Quality in Ekpoma, Edo State, Nigeria. Global Res. J. Microbiol., 4(1): 1-5.

Qudiesat, K., Abu-Elteen, K., Elkarmi, A., Hamad, M. andAbussaud, M. 2009.Assessment of airborne pathogens in healthcare Settings. African $J$. Microbiol. Res., 3(2) pp. 066-076.

Reijula, K., Sundman-Digert, C. 2004. Assessment of indoor air problems at work with a questionnaire. Occup. Environ. Med., 61: 33-38.

Ross, C., de Menezes, J. R., Svidzinski, T.I.E., Albino, U. and Andrade, G.2004.Studies on Fungal and Bacterial Population of Air conditioned Environments. Brazilian Arch. Biol. Technol., 7(5): pp. 827-835.

How to cite this article:

Muna M. Buzayan and Fauzia R. El-Garbulli. 2017. Microbial Air Quality in Medical Laboratory Rooms at Benghazi Center of Infectious Diseases and Immunity. Int.J.Curr.Res.Aca.Rev. 5(3), 71-79.

doi: https://doi.org/10.20546/ijcrar.2017.503.011
Park, D., Yeom, J., Lee, W.J. and Lee, K. 2013. Assessment of the Levels of Airborne Bacteria, Gram-Negative Bacteria, and Fungi in Hospital Lobbies. Int. J. Environ. Res. Public Health, 10: 541-555.

Pasquarella, C., Pitzurra, O. and Savino, A. 2000. The index of microbial air contamination. J. Hosp. Infect., 46: 241-256.

Shelton, B.G., Kirkland, K. H., Flanders, W.D. and Morris, G. K. 2002.Profiles of Airborne Fungi in Buildings and Outdoor Environments in the United States. Appl. Environ. Microbiol., 68(4): 17431753.

Stryjakowska-Sekulska, M., Piotraszewska-Pająk, A., Szyszka, A., Nowicki, M., and Filipiak, M. 2007. Microbiological Quality of Indoor Air in University Rooms. Polish J. Environ. Stud., 16(4): 623-632.

Toth, C. 1992. Microbial in the overall context of indoor air quality investigation. Proceedings of the First Annual IAQ, Conference and Exposition, pp. 255259.

World Health Organization. 1988. Indoor air quality: biological contaminants. World Health Organization, European Series, n. 31, Copenhagen, Denmark. 